\title{
Playing with Knowledge: \\ Sport and the Paradox of Development \\ in Solomon Islands
}

Tom Mountjoy

There has never really been a coherent policy for the development of sport in this country. Politicians are always trying to find out where sport fits into official policy. You see how sport has been thrown back and forth between different ministries over the years. It is a grey area for the government; it has been for successive governments since independence. It seems to boil down to money issues, but also a lack of willpower, and maybe too many stubborn people. This just goes to show the lack of initiative taken to firmly place sport alongside the education and development of the youth and see its benefits to the nation as a whole. It should be left for the people to decide, not these guys in suits.

- John Bakeua, Director of Sport, Solomon Islands Ministry of Home Affairs ${ }^{1}$

\section{Tracing Development through Local Epistemologies}

Simmering unease throughout parts of Solomon Islands in the I990s culminated in the start of a five-year period of civil discord (I998-2003) often referred to as "the Tensions." 2 Despite various political attempts at resolving the ongoing and often violent feuds between rival militias mainly from Malaita and Guadalcanal provinces, by 2003 the nation was all but bankrupt and state services had all but ceased to operate. Against this backdrop, a remarkable success story stood out. Sport, and more specifically soccer, rose to national prominence in the early years of the new millennium due to a series of outstanding results abroad (see Mountjoy 20I3), and it provided a much sought after outlet for a coherent expres-

The Contemporary Pacific, Volume 26, Number 2, 325-345

(C) 2014 by University of Hawai'i Press 
sion of unity, which had been missing amid all the suspicion and turmoil of the previous decade. Off the field, however, discourse surrounding the way sport was to "develop" was far from unified. In this article, I discuss ways in which such divergences can be seen to reflect different epistemologies concerning not just sport but the future of the nation itself. The contrasting ideas of development and knowledge diffusion surrounding soccer in Solomon Islands are shown to be entwined within the complex set of practices, structures, strategies, and contexts that constitute contemporary development discourse in the Pacific. Rather than viewing these interactions in a Foucauldian sense of abstract, power-invoking, and legitimizing struggles, in this article I use examples from my interactions with key stakeholders to straddle the common top-down demarcation of sport development and local pragmatic cognitive understandings of the development path. ${ }^{3}$ While these projects contain the hallmarks of the most widespread type of development structure, including financial support, training, infrastructure enhancement, and awareness campaigns, it is the social level of knowledge dissemination that is of interest in this analysis.

The inevitable differences between the logics of the "developers" or those with "specialized" understanding of the game vis-à-vis the local actors are often viewed within neoliberal idioms of economic management and rational "progression" that tend to overshadow the epistemological experiences such processes reveal locally. Referring to this type of populist ideology and rhetoric as an impediment to anthropological inquiry, JeanPierre Olivier de Sardan has advocated a participatory stance in the production of more "reliable" knowledge (2005). I critically view the development agenda taking place in Solomon Islands sport through the lens of methodological populism, which both elaborates and acknowledges local strategies and rationalities yet deromanticizes their contextual "value or validity" (Olivier de Sardan 2005, 9). This agenda, in turn, is part of a global push in recent years to "remobilize sport as a vehicle for broad, sustainable development" (Kidd 2008, 370), an effort that, I argue, remains embedded in institutionalized notions of modernity.

Drawing on the various soccer-related encounters in Solomon Islands that I experienced during my 2009-20I I doctoral research, I offer here an alternative view of development as an arena wherein local stakeholders use Western ideas about the game as creative conduits for indigenous analysis and program design. My analysis of these encounters is, by methodological default, not connected with any philosophical traditions that aim for a totalizing conception of a newer Melanesian anthropology of 
development. The interactions and social events I have been involved with have been inextricably linked to a period of emergent modernity in which soccer in Solomon Islands is embracing forms of globality that blur the boundaries between Westernized concepts and local realities. It is within this crossover that sport can be seen to emerge as a new and effective lens through which asymmetries inherent in Western/non-Western development encounters can be critically recontextualized. These logics are seen to constitute continually emerging social realities that, while scarcely new when seen from a historical perspective throughout Melanesia, are yet indicative of the unique way in which sporting engagement today reflects the opportunity for what Marshall Sahlins described as "the enrichment of their [ie, Pacific Islanders] own ideas of what mankind is all about" (I992, I4). My reading of Sahlins in relation to sporting development does not lean to the often-unintended subordination of capitalist cosmologies in favor of augmenting traditional relationships and exchange patterns; rather, I see it as an approach that theoretically merges particular development strategies with the dynamics of social, political, and economic change.

There may be no clearer example of the importance and scope of soccer in Solomon Islands than that provided by Elliot Ragomo, the widely cherished captain of the national indoor soccer team. While this young player has certainly been key to the dominance of the team in Oceania and successive FIFA futsal World Cup appearances, ${ }^{4}$ he is also central to the postconflict psyche of the nation. Besides being named the inaugural national Sportsman of the Year in 20I0, Ragomo was also awarded the Young Solomon Islander of the Year award by the Ministry of Women, Youth, and Children's Affairs in recognition of his achievements in contributing to the development of a nation struggling to rebuild its confidence severely tarnished by the Tensions (FijiLive 20II). His narrative is as much a sporting story as it is a window into the complex youth moralities at play in a modern-day Melanesian nation (Mountjoy 20I3, 200-207). In a personal interview in February 20I0, Ragomo told me:

When I was growing up things were difficult, especially with the Tensions, and everyone was worried about the future. I didn't think that playing soccer and going to school then church would actually get me to this place where I am now, but I see how it has been part of what brings people together. This is just what was missing during the Tension period: the simple things that we have back in the village like going to church, helping our families, and thinking about how we can achieve something and become successful in the future. Soccer is a game we all play, but [it] teaches us responsibility and the idea of 
cooperation, as a team and as a nation. I could go and play overseas, but I prefer it here. I prefer to see the kids looking up to me and not thinking about all the differences and troubles we have been through.

Exemplifying the role that soccer plays in transcending the immediate conditions of the post-Tension period, Ragomo had quickly become a symbol for reimagining and demonstrating the possibilities that lie beyond the nation. Although his actual experiences overseas may be incomprehensible to the majority of his peers, Ragomo epitomizes the youthful Melanesian facing the realities of constantly framing his soccer-oriented identity within a coalescence of evolving local and global processes (strikingly similar to the young men who in the early twentieth century returned after periods of labor in Queensland or pastoral training in New Zealand or on Lord Howe Island).

Melanesians today find themselves in a position to contrast their epistemic capacities in a pluralistic sense when confronted by foreign influence, whether through development encounters, tourism, political engagement, or sporting competition. This means that the contradictions inherent in the "evaporation of the moral certainties that colonialism has simultaneously enforced and enabled" (Thomas 1997, 23) reveal themselves in mundane elements of civil life, played out on the sports fields and in the church halls. Ideas and knowledge gained from encounters with Western peoples are no longer viewed as revelations in a perplexing sense, requiring complex coping mechanisms, but are instead merged by Solomon Islanders into their worldview of maintaining simplicity in a rapidly changing sociopolitical climate. Soccer, as an imported practice, is positioned in Solomon Islands according to various dynamics of connectivity and exchange born out of social and political relations. Reference to forms of "complexity" vis-à-vis "simplicity" extrapolated from foreign developmentalist approaches can be seen as inconsequential if the global game of soccer only has effectiveness prior to any localized translation or transformation (Appadurai I996). The development encounter throughout Melanesia, despite anxieties facing the region today, can be seen as an arena "for making the unpredictable predictable, and for seeking mutual interpretations of what the others are all about" (Hviding I998, 49). This convergence is as applicable today in terms of FIFA, RAMSI, and AusAID efforts to help Solomon Islands emerge from ongoing instability as it was during earlier historical encounters in the region, ${ }^{5}$ although "the mechanisms of heterogenization and homogenization" (Friedman I997, 269) remain poorly formulated. 


\section{fifa: The Politics of Development}

In order to help clarify how these contrasting interpretations come about, in this section I sketch the background to recent soccer development in the Solomons and the agents involved. Over the past decade, representatives of the Solomon Islands state have quietly been using the successes of sport (in particular the remarkable achievements of the Kurukuru and Bilikiki) to make public appearances for their own political gain and expedience. ${ }^{6}$ Soccer, however, is administered by the Solomon Islands Football Federation (SIFF) as a non-state-run federation with partial managerial control of large sums of money that are being channeled through FIFA via the Oceania Football Confederation (OFC $)^{7}$-a recent example being the release of Us $\$ 50$ million from FIFA for development in Oceania for the period 20II-20I9. This has made positions on the SIFF board subject to increased public scrutiny due to the fact that aside from members of Parliament or major landholders with dealings with foreign timber or mining consortiums, few have access to such high levels of overseas development funding. Like many members of parliament, SIFF has become adept at using the language of morality, nationhood, and leadership through its stated desire to abide by the aims laid out in FIFA statutes. Typical of these are FIFA slogans such as "Sport for all," "For the game. For the world," and "Build a better future." This language, I argue, echoes that from the early era of missionization and throughout the colonial period whereby legitimacy was established through the introduction of education, sport, and the dispersal of knowledge surrounding moral and physical health. These tactics often had more subversive intentions such as the pacification of locals and easier means of acquiring lands and labor.

Members of the Solomon Islands public are extremely suspicious of the fundamental soccer "project" taking place today, largely resulting from the backing of funds from the OFC. Conceptualized locally in vernacular terms, the Melanesian "porojek" bears only superficial resemblance to the globally defined development "project." Indeed, projects today are often manifested as "as much a part of Melanesian kastom as of Melanesian modernity," leading to varying degrees of collaboration between locals and foreign agencies who may operate with differing agendas and motivations "even to the degree of ontological incompatibility" (Hviding 2003, 544). Outside Honiara, and more recently in Gizo, development of sporting infrastructure has been slow to nonexistent, despite years of promises from federation officials. If anything, much of this seems to stem from 
the lack of provincial leadership and cooperation with the SIFF base in Honiara. Steps to develop the game rurally are largely in the hands of various church-based organizations with their wide voluntary networks (see figure I) as well as individual parliamentarians and business holders. In many respects, however, sIFF finds itself in a difficult position with regard to fully implementing its internal constitution, with the majority of its income and development agenda coming from overseas agencies. Public dissatisfaction is often vented through the media and is usually expressed in ways that link the lack of progress in fully implementing developmental initiatives with perceptions about how FIFA money is handled. This continuing discourse, which is often based not so much on facts as on assumptions, is not made clearer by the haphazard operations of SIFF provincial member associations. Changes in personnel are frequent, and elections are often held without allowing full participation of all interested parties. This is not to imply favoritism or misjudged motives; rather, it is perhaps a sign of the many difficulties inherent in structuring unified organizations in a nation as diverse as Solomon Islands and, indeed, throughout Melanesia (LiPuma 200I).

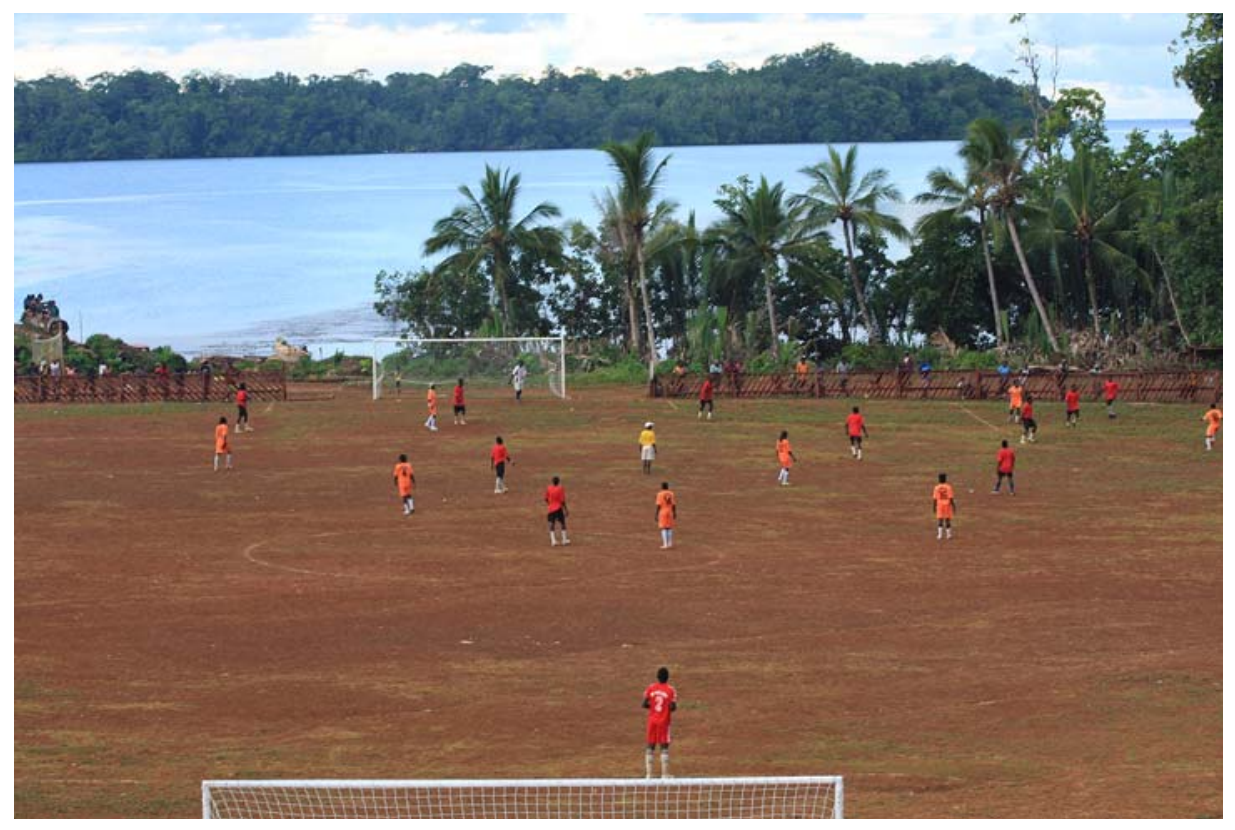

FIGURE I Christian Fellowship Church annual sports tournament, Marovo, Solomon Islands, December 20I0. Photo by author. 
One may compare this skepticism with the conceptual analysis of "bisnis" and "diflopmen" in the Kwara'ae region of Malaita (Gegeo I998, 200I; Gegeo and Watson-Gegeo 2002). While these two concepts are often used interchangeably in formal discourse, "the distinction is less between kinds of projects than between goals and strategies" (Gegeo 1998, 306). Doing "bisnis," which in many soccer-related cases becomes conflated with "diflopmen," quickly takes on negative connotations through being viewed as a "dead" mode of production stemming from introduced colonial knowledge and practices (Gegeo I998, 30I). In contrast, the "alive" natures of localized forms of "diflopmen" become apparent when indigenous epistemologies are principal to processes of "constantly (re)theorizing, (re)creating, and (re)structuring knowledge" (Gegeo and Watson-Gegeo 2002, 38I). While the Kwara'ae case examines rural development from within, the similarities with the soccer "project" taking place throughout Solomon Islands are notable. Development from outside remains largely bound to a modernization paradigm that emphasizes Western-based knowledge systems at the expense of existing knowledge resources and practices. This does not necessarily mean that all outside help is unwarranted or unsuccessful-indeed few regard the success of soccer in the past decade as disassociated from the efforts of FIFA-but it highlights significant social and political complexities that are deficient from ongoing development initiatives (as also discussed in Clément's and Kwauk's articles, this issue).

\section{Soccer Stakeholders' Meeting, Honiara, January 20 io}

To gauge both the enthusiasm and the frustration bound up in soccer in Solomon Islands, one need only spend a few days walking down Mendana Avenue in Honiara chatting with the locals. Everyone has an opinion on the state of the game, its past history, and the problems it faces in developing for the future. While this methodological approach has proven vital in the accumulation of materials and understandings of the urban context of soccer, it has been a challenge to sort through the myriad perspectives, given that almost everyone claims a sense of authority.

Solomon Islands is an archipelago nation spread over a vast geographical space yet small enough in many respects to generate broad insights in very concrete settings. It is not uncommon to find oneself in the middle of an event or setting epitomizing multilayered diversity. Such an example occurred early in January 2010 at the Mendana Hotel in Honiara, where 
SIFF and the OFC arranged a "soccer stakeholders meeting," held over the course of a full day and including representatives from the entire spectrum of parties interested in the development of soccer. Along with twentyfive invited "stakeholders," two senior OFC officers were present, Glenn Turner (FIFA Development Officer for Oceania) and Greg Larsen (OFC Deputy General Secretary). They were joined by SIFF President Martin Alufurai and SIFF General Secretary Eddie Ngava. The scene soon took on the appearance of an inquisition, with the "host" delegates assuming the role of "informing" and at the same time "defending" themselves and their policies in the face of questions from the stakeholders. I saw the meeting as a chance for both SIFF and the OFC to defend the legitimacy of their operations, especially in terms of being accountable for the implementation of various development programs as well as having a transparent board structure. Both of these issues had received considerable media attention in the months before the meeting, and this was reflected in the majority of soccer-related discourse on the streets and local media channels I was constantly surrounded by. The overall vision of SIFF was stated at the beginning of the day by Ngava: "to develop and improve continually the standard of football as the number one sport in the country by encouraging and increasing participation in our sport at all levels of our communities, while aspiring and striving to become a competitive and successful nation internationally."

The invited guests included representatives from the government education and home affairs departments, churches, media organizations, sponsors, and sports administrators. Aside from the OFC representatives, I was the sole "outsider" or non-Solomon Islander present and I introduced myself as an overseas researcher interested in the future development of the game. The general mood of the meeting was cooperative in the sense that all parties had the future success of soccer in the country at heart, but an underlying sense of discord was apparent in the slow and sometimes backsliding nature of the discussion. The OFC representatives obviously had a pre-prepared presentation in which Larsen discussed the administrative workings of the OFC and their budgeting structure, which included how funds and projects were dispersed and managed in Solomon Islands. Money, he reminded everyone, was tightly controlled from the central offices in Auckland, and sIFF merely acted as "managers" for the various OFC projects taking place in Honiara and also in Auki and Gizo. Having access to managerial privileges over large sums of development spending was a unique arrangement for SIFF in terms of other sport 
or civil society bodies, and with this came extended scrutiny and general public mistrust.

Why, asked Larsen, was SIFF getting so much bad press coverage and attracting public disapproval, "when all they were doing was trying to improve the quality and infrastructure of the game throughout the land?" This rather simplistic appraisal was maintained throughout the meeting, and it was more often than not met with rolling eyes from the majority of stakeholders and nervous glances from the SIFF officials. All knew that a simple desire to promote the game for the good of the nation did not automatically guarantee accountable and efficient operational procedures. In essence, the question Larsen raised epitomized the disparity between local understandings of what was needed to improve the game and its structures, and the confusion and frustration experienced by overseas development agencies such as the OFC. In a personal interview in Auckland the following month (February 20I0), Turner suggested that the solutions "may never be fully decipherable" but that "then again, maybe that shouldn't be the ultimate aim."

As the governing body in charge of soccer, SIFF is one of the most powerful nongovernmental bodies operating in Solomon Islands. With SIFF in charge of overall soccer development throughout the nation and acting as caretaker of considerably well-funded FIFA special projects, it is not surprising that every move of the federation and its leaders is closely scrutinized by the entire nation. In the decade following the end of the Tensions, various media channels had raised questions about the feasibility of particular projects, given the seemingly unstructured organizational framework SIFF had in place outside the capital. I had met Ngava during my first trip in early 2009 and from our interaction gained some understanding of the difficulties facing SIFF and their uncertain relation with the media and general population. Having detected a strain in public relations early on in my fieldwork, I saw the stakeholders meeting as an ideal opportunity for the face of soccer in Solomon Islands to present itself in a more open way, which would help point to the inclusive nature of their national constitution and developmental aspirations.

As the January 20 Io meeting had been arranged on rather short notice, few members of the public had time to dwell on its symbolism, other than to express comments similar to those of Michael, a local coach: "They [SIFF] realize that the public is getting tired of the secrecy and the lack of real results from all this funding from FIFA. Everyone just wants to see kids playing on good fields, with proper balls and goals. We know politics 
is a fishy business here, but this is about soccer, and surely they can understand that. I think the meeting is good, but you must tell them [SIFF and the OFC] that we are fed up with all the excuses. The kids deserve better."

The relationship between the OFC and SIFF was repeatedly discussed during the meeting in terms of financial and administrative measures. It was evident that SIFF had the full backing of the OFC regarding the manner in which the federation was handling local affairs and developing the game, but there was constant reiteration of the idea that the entire soccer project would need the assistance of all stakeholders if the restructuring and developmental process was to continue its successful progression. Turner explained that the newly established FIFA Goal projects are implemented by an externally vetted FIFA contractor, who appoints local subcontractors. SIFF receives the completed project, be it a playing field or building. SIFF is the recipient of the project at completion, Turner explained, but never receives any FIFA Goal project finance.

The objective of the meeting, as outlined by Ngava, was that of informing stakeholders of the details surrounding the environment within which SIFF held its mandate to operate as an affiliate member organization of the OFC/FIFA. He reminded the audience that much of the media coverage was misinformed and based on the spurious notion that SIFF conducted its own internal audit and had control over development cash spending. The purse was held in Auckland, and the subcontractors were managed through the federation in Honiara, we were again told. I later met both Turner and Larsen at the Auckland headquarters of the OFC to discuss post-Tension soccer development in Solomon Islands, gaining a deeper insight into the operations of soccer at a political level in the Pacific. All the money SIFF received from the OFC, I was told, was subject to stringent rules and regulations handed down from Auckland in order to ensure continued receipt of development assistance. Back in Honiara, Larsen confronted questioning from the media and others regarding accusations of mismanagement by simply stating that if money went missing or was not channeled directly into the agreed-on projects, "we would be the first to know." A glance around the table was enough to conclude that the majority thought this statement to be rather naive, given the lack of progress on major OFC-funded development projects throughout the country.

The discussions culminated in the realization that SIFF was in fact the only official channel through which stakeholders could vent their frustrations about a seemingly slow development process. Operating alone, SIFF was certainly unable to meet the expectations of infrastructural develop- 
ment placed on it by the general public, especially considering the vastness of outlying provinces and the difficulties in improving basic infrastructures. Discussions circled the table as to how best to work in a cooperative manner to solve some of the long-standing issues that the general public perceived to be stalling real progress in local soccer development. The members of the group were clearly united in their passion for the game, yet unity in views and concrete policy plans and hopes for implementation seemed far off. Similar concerns were shared by high-ranking public servants, represented by division directors Aseri Yalangono from the Ministry of Education and John Bakeua from the Ministry of Home Affairs. They each made reference to the positive impact that sporting participation, especially through soccer, had made during and following the Tension years. The large youth population needed sport to be backed by the authorities in more ways than it was currently, and sport provided vast numbers of people with a positive avenue through which to contribute to the "Christian values this country stood for," explained Bakeua.

SIFF President Martin Alufurai closed the meeting by stating again the need for cooperation on all fronts if development and expectations were to be met. He was content that the intended objectives of renewing discussion and clarifying SIFF's position had been achieved and said that he felt that "the participants [could] leave satisfied and that this meeting will set the pace for further advancement throughout this year and into the future." The need for a clear proposal to be drawn up based on the outcomes of the workshop for submission to the appropriate bodies including the government was repeatedly mooted at the end of the meeting, both by the SIFF representatives and the stakeholders, although no formal memorandum was signed following the meeting. When I spoke afterward to John Bakeua, he told me that such proposals had been suggested in the past but had never reached the stage of being officially presented to the government. As was exemplified during this meeting, Bakeua said, "People may seem to agree on the table, but afterwards the old conflicts come back and nothing can be agreed upon."

The meeting vividly portrayed some of the difficulties facing theories relating to development and modernization "dictated from the outside" concerning notions of "building capacity," "accountability," "fairness," and, indeed, "nation" (Gegeo I998, 289). Operating structures continue to be rooted in community-based civil society models that form a hybrid notion of a Solomon Islands nation-state. These structures and their narratives are amalgams of unity and dissent and, as such, become paradoxi- 
cal in relation to more formalized rationales such as those conveyed by FIFA. There is certainly no lack of will on the part of the vast majority of the population to see soccer develop and participation grow, but deeply entrenched differences make collaborative measures difficult to impose. So often the discussion came down to the question of finances and their "proper allocation"-questions that were mired in accusations and distrust. In a country where little money flows through the sporting scene generally, soccer is seen to be in a privileged position due to its close affiliation with the governing body, FIFA. Funds, as explained privately to me by Larsen, are certainly not distributed without accounting for them, yet the scale of some of the projects and the condition of the visible infrastructure understandably leaves questions posed by the media and general public unanswered. The ofC, Turner explained to me, had an obligation to account for funds allocated through particular FIFA development projects. When subcontractors were hired and local management practices were seen to hinder or complicate such initiatives, he said, "there is very little we can do about that, as that is a question of local management responses to circumstances we have little or no control over."

\section{Future Priorities and Contested Coherence}

While progress (infrastructural and economic) has been painfully slow for many "stakeholders" and followers I met, a decade on from the easing of the Tensions reveals a thriving sport bursting at its seams with unsurpassed passion. However, the extent to which this progress has to do with an increased focus on development is far from clear. Like the International Olympic Committee, FIFA continues to promote an agenda that assumes an (overtly generalized) universal social usefulness of sport, which requires measurement, evaluation, and professionalism in order to achieve its effectiveness. In fact, a number of the FIFA funding programs are dependent on member nations meeting annual guidelines laid out by officials in Zürich (FIFA) or Auckland (OFC). From a social perspective and its manifestation in official global policy development, the apparent role of sport is largely reliant on a coherent structural framework in order to achieve (taking a prominent example) the United Nations Millennium Development Goals. ${ }^{8}$ While sport policy continues to seek "better integration into the development agenda" through "partnerships ... according to locally assessed needs" (UN Department of Public Information 2005, v), frameworks cannot be bound by narrow, unreflexive, and symbolic struc- 
tural understandings intent on mainstreaming the use of sport. The paradox of this "better integration" of sport policy echoes in many respects the ways indigenous epistemology as "a cultural group's ways of theorizing knowledge" (Gegeo and Watson-Gegeo 200I, 55) struggles to implement further stages of dehegemonization (Gegeo I998, 200I).

The future priorities outlined by the OFC for the period up to 2018 rest to a large extent on being able to circumvent political issues and features typical of Melanesian interpersonal relations that have proved hindrances to initial stages of soccer-related development. The future vision in the Activity Report 20 Iо (OFC 20IO) is very much in line with FIFA's intention to assist in the spread of standardized reform and development on a global scale, with specific locally defined objectives. It is within this meso-macro framework that the future successes and failures of development visions, such as those of the OFC, will be mediated. As Christina Ting Kwauk's contribution to this special issue suggests, policies and practices are continually reimagined in Samoan sport assemblages, often in contrast to more dominant international development paradigms. The particular paradox of development I have attempted to portray here could well be true for sport across the Pacific, in the struggle to apply multiple local interpretations of the efficacy of both sporting practice and the visions of what rewards may bring to both individuals and communities. It is clear that the risk/reward equation related to sport development is one that cannot be adequately standardized, and the patriarchy of FIFA and the United Nations must be contextualized within the broader realm of contemporary social, political, and economic potentials of Pacific Island states-in other words, there needs to be a shift toward actualities involving Pacific people, who may not necessarily fit into the structural logics through which Western development agencies continue to define their policies.

Foreign interaction today revolves around social practices and strategies that are based on quite different agendas from those of the colonial era, as is evident in the contemporary soccer development scene in Solomon Islands. The division of multiple ideas, logics, and practitioners involved in soccer-related discourse remains apparent as an evolving aspect of modernity bound up in this interface, and the situation clearly highlights the disparities inherent in forging an amalgamated development structure. Soccer projects are presented to Solomon Islanders without any clear demarcations as to who is in control, with stakeholders seemingly unwilling to recognize authoritative pronouncements coming from "agents" of superior knowledge. This then reveals development measures 
forged by FIFA and the Australian government and associated organizations as relating more to a "particular epistemology that sees the world in universalistic terms" (Sillitoe 2010, 24) than to more subtle contexts of local epistemologies and experience (Gegeo I998, 200I). Stakeholders view the importance of soccer as being embedded deep within multiple aspects of a society that renders increasingly problematic the master narrative of Western forms of knowledge accumulation, interpretation, and dispersal relating to sport development. While the "goals" may appear to be shared, as was evident at the stakeholders' meeting, the path to achieving particular development targets becomes paradoxical when attached to a narrative genre that fails to fully encapsulate the complexities inherent in local discursive frameworks (Gegeo I998).

Funding and education initiatives are thus fraught with difficulty in a region lacking the structures and agencies typically required by development organizations to adhere to their hierarchical levels of project organization. However, sport remains an arena that presents individuals and groups alike with multiple opportunities to reconsider and reconstruct their relationships with one another as well as with the challenges presented by new forms of knowledge. The points of intersection and disparity between local and foreign stakeholders are clearly apparent when trying to reconceptualize the idea or concept of shared practice and knowledge encounters and their normative extent within the framework of contemporary Solomon Islands. As highlighted by both Kwauk and Julien Clément in this issue, the dynamics of "sport for development" continue to provide disconnects between naive assumptions applied in equal measure to local processes and to the perceived power of sport.

\section{Conclusion: Contesting Policy and Practice}

On the playing field, styles of performance reflect the multiple social, symbolic, and political realms of young sportsmen and sportswomen, making essentialized notions of sporting practice and practitioners difficult to justify, let alone sustain (Mountjoy 2013). This, I argue, can be extended beyond Melanesia and throughout the Pacific, where the development agenda still seeks an authentication or indigenization of a homogenized Oceanic culture. The strength of rural church- and kin-based groups throughout Solomon Islands points to the role that noneconomic or politically oriented development mandates have in parts of rural Melanesia. Development becomes not an act separate from everyday life but rather 
a component of participation in multiple social realms with differential impacts in dissimilar contexts. These localized translations and transformations that occur through various forms of soccer, especially since the Tensions, bring into question the wider social and political context of development in the region. The analysis of local and transnational development rhetoric and practice is difficult to place within Westernized neoliberalist models of state-nation-society "empowerment," as exemplified by FIFA. This becomes immediately contested within the parameters of development programs that seek to categorize particular sectors of society in order to mirror policy frameworks. In Solomon Islands, no clearly defined institutional framework exists through which sport policy can be organized along quantifiable lines of implementation and evaluation. The complex aesthetics of the soccer culture in Solomon Islands can perhaps parallel certain ways in which colonial power was both dispersed and legitimized throughout Melanesia (see Mountjoy 20I3). These days, development initiatives for FIFA's "global game" are indicative of a paradox found throughout the world that presents soccer as a unified cultural code, at the same time as local epistemologies continue to make the game their own. The Solomon Islands "soccerscape" (Alegi 20I0) can be seen as an illustration of the complex nature of "modernity at large" (Appadurai I996), which subversively undermines the logic of a global development agenda by asking, "What do they know of soccer who only soccer know?"9

Foreign agencies may find the tools for implementing development agendas embedded within the people at community levels but not bound within structural frameworks drawn up from afar. The paradox I have outlined in this article is a complex one, as it is entangled within the discursive notions through which the salience of development goals is mediated. Ideas of "efficiency" and "accountability" have long become attached to the perceived "weakness" of Melanesian states, yet identities and aspirations of local stakeholders operate outside these paradigms. As Paige West has previously noted in her description of conservation and development in Papua New Guinea (2006), a profound disconnect between the goals of the locals and those of overseas agencies takes place. While I do not attempt to conflate sport with the political ecology of conservation, the reference is applicable regarding the subjectivities of those involved in defining what development is and what it might become. Overseas agents have become embroiled within a multisided discourse of social, economic, and political ideals relating not only to soccer but also to contemporary power rela- 
tions and aspirations of change. The paradox that sport exposes cannot be reduced to differing "development agendas" or even to the difficulties that foreign agencies face working within paradigms based on a presumed national sociopolitical coherence-something Solomon Islands and other Melanesian states do not share. The paradox relates more to the way the divide is embedded in the very social relationships that continue to forge both unity and discontent in contemporary Solomon Islands society.

This article has looked at measures taken to promote soccer in Solomon Islands, within the framework of contestable coherence as evident in the language used to describe sport and its future benefit to the nation. It seems clear that the particular methodologies employed by outside agencies cannot fully account for the complex social and political systems in which policy based on populist ideology is intended to deliver salient outcomes. For Olivier de Sardan, this style of rhetoric can be politically naive in the way it "paints reality in the colours of its dreams" $(2005,9)$. Sport, in all its complexity, offers a number of possible benefits to Pacific nations, many of which are taking place away from the gaze of a "sport for development" ideology that is largely insulated from local conditions. As this special issue clearly highlights, sport is not a uniform phenomenon and hence cannot be seen as a universal solution to wider social issues facing the Pacific due to the multiple ways in which it finds its expression and understanding. As an embodied life projection, ${ }^{10}$ sport offers potentially enlightening ways of freeing dogmatic "capacity building" ideology from its mire of binary oppositions, especially apparent through the idiom of development. Sport can be included in future development policies in Solomon Islands only if its standing beyond the institutional and organizational realm of structured agencies, both within and outside the nation, becomes theorized and applied through local strategies and understandings. Various development practices need not discard logical models of skills, equity, community regeneration, and so forth, but they can only be fully realized in a localized context through wider participation and recognition of the dynamic, multivocal narrative that gives meaning and context to everyday Solomon Islands epistemologies.

I EXTEND MY GRATITUDE to the Association for Social Anthropology in Oceania for providing such a convivial space for the conversations reflected here to develop over the years, and to the many participants who contributed to the sessions culminating in this special issue. Earlier versions of this article also benefited from 
encouraging comments from the Bergen Pacific Studies Research Group, especially Edvard Hviding. I thank the three external reviewers for their critical and insightful comments and of course take full responsibility for any inaccuracies.

\section{Notes}

I John Bakeua made this statement during an interview conducted at the Ministry of Home Affairs in Honiara, I 5 January 20 IO.

2 The period of civil, economic, and political disruption at the turn of the century throughout parts of Solomon Islands has commonly been referred to as "the Tensions," a broad term intended to avoid the oversimplified label of "ethnic conflict” (see Dinnen 2002; Kabutaulaka 2004; Fraenkel 2004; Moore 2004).

3 The use of "stakeholder" here is taken from conversations I had in Solomon Islands during a "stakeholders" meeting, discussed later. Individuals, groups, societies and organizations that had any interest in the future of soccer were deemed stakeholders. It could refer to a volunteer or a senior politician, but the term was accepted to be "self-defined" as a vernacular term for the arena of meetings by those who were in attendance and also an eloquent example of appropriating concepts from the "development" discourse for vernacular use.

4 The Fédération Internationale de Football Association (FIFA) is the international governing body of association football (soccer), with Solomon Islands being one of 209 national associations. Futsal is a variant of association football that is played on a smaller pitch and mainly indoors. The Oceania Football Confederation (OFC) oversees the operations of soccer in Solomon Islands.

5 I choose to focus on the direct soccer-development initiatives and rhetoric relating to FIFA and the OFC in this analysis, without in-depth study of an array of Australian-led programs funded and administered by the Regional Assistance Mission to Solomon Islands (RAMSI) and the Australian Agency for International Development (AusAID). For more on these programs and their sociopolitical effects, see Kabutaulaka 2005, Moore 2007, Hameiri 2007, Allen 2009.

6 Named after Solomon Island coastal birds, the Kurukuru and Bilikiki are the national indoor (futsal) and beach soccer teams, respectively. The Solomon Islands teams have been the most dominant in Oceania for the past decade and have reached numerous FIFA World Cup final tournaments since 2006.

7 As the sixth and smallest continental federation incorporated into FIFA, the OFC was founded in 1966 but only formally confirmed as a full federation in I996. Solomon Islands is one of eleven full member associations in the confederation and has been the recipient of a number of "special projects" that FIFA has launched in recent years under the "solidarity" principle underpinning FIFA's Financial Assistance and Goal Programmes. Besides serving and administering 
the soccer-related competitions and development projects throughout the region, the OFC follows FIFA's undertaking to use the game as a "tool for social development," clearly stated in the new vision of the OFC: "to raise the overall standard of football in Oceania and utilize the power and passion of football to help promote education, community development, capacity building, health awareness, cultural exchange and economic development within the football community” (OFC mission statement, 20I0).

8 See UN Interagency Task Force on Sport for Development and Peace 2003.

9 Here I rephrase the line from Rudyard Kipling's poem "The English Flag”: "What should they know of England who only England know?" This was famously revised by C L R James in his preface to Beyond a Boundary as: "What do they know of cricket who only cricket know?" (I993, xxi).

Io For a more thorough elaboration of the corporeal understandings and experiences of sport in Solomon Islands and how they relate to particular theories of Melanesian forms of sociality, past histories, and environment, see Mountjoy 2013 .

\section{References}

Alegi, Peter

2010 African Soccerscapes: How a Continent Changed the World's Game. Athens: Ohio University Press.

Allen, Matthew

2009 Resisting RAMSI: Intervention, Identity and Symbolism in Solomon Islands. Oceania 79 (I): I-I7.

Appadurai, Arjun

I996 Modernity at Large: Cultural Dimensions of Globalization. Minneapolis: University of Minnesota Press.

Dinnen, Sinclair

2002 Winners and Losers: Politics and Disorder in the Solomon Islands 2000-2002. Journal of Pacific History 37 (3): 28 5-298.

FijiLive

20 I Ragomo Scoops Prestigious Award. 3 November. http://fijilive.com/

Fraenkel, Jon sports/news/20I I/I I/03/24309.Fijilive [accessed 2I Feb 20I4]

2004 The Manipulation of Custom: From Uprising to Intervention in the Solomon Islands. Wellington: Victoria University Press.

Friedman, Jonathan

I997 Global Crises, the Struggle for Cultural Identity and Intellectual Pork-Barreling: Cosmopolitans, Nationals and Locals in an Era of De-Hegemonization. In Debating Cultural Hybridity: Multi-Cultural 
Identities and the Politics of Anti-Racism, edited by Pnina Werbner and Tariq Modood, 70-89. London: Zed Books.

Gegeo, David Welchman

I998 Indigenous Knowledge and Empowerment: Rural Development Examined from Within. The Contemporary Pacific Io:289-3 I 5.

200I Cultural Rupture and Indigeneity: The Challenge of (Re)visioning "Place" in the Pacific. The Contemporary Pacific I3:49I-507.

Gegeo, David Welchman, and Karen Ann Watson-Gegeo

2002 Whose Knowledge? Epistemological Collisions in Solomon Islands Community Development. The Contemporary Pacific I4:377-409.

Hameiri, Shahar

2007 The Trouble with RAMsi: Reexamining the Roots of Conflict in Solo-

Hviding, Edvard mon Islands. The Contemporary Pacific I 9:409-44 I.

I996 Guardians of Marovo Lagoon: Practice, Place, and Politics in Maritime Melanesia. Pacific Islands Monograph Series I4. Honolulu: Center for Pacific Islands Studies and University of Hawai'i Press.

I998 Western Movements in Non-Western Worlds: Toward an Anthropology of Uncertain Encounters. Journal of the Finnish Anthropological Society 23 (3): 30-5I.

2003 Between Knowledges: Pacific Studies and Academic Disciplines. The Contemporary Pacific I 5:43-73.

Kabutaulaka, Tarcisius Tara

2004 Melanesia in Review: Issues and Events 2003; Solomon Islands. The Contemporary Pacific I 6:393-401.

2005 Australian Foreign Policy and the RAMSI Intervention in Solomon Islands. The Contemporary Pacific I 7:283-308.

Kidd, Bruce

2008 A New Social Movement: Sport for Development and Peace. Sport in

LiPuma, Edward Society I I (4): 370-380.

200I Encompassing Others: The Magic of Modernity in Melanesia. Ann Arbor: University of Michigan Press.

Moore, Clive

2004 Happy Isles in Crisis: The Historical Causes for a Failing State in Solomon Islands, I998-2004. Canberra: Asia Pacific Press.

2007 Helpem Fren: The Solomon Islands, 2003-2007. The Journal of Pacific History 42 (2): I4I-I64.

Mountjoy, Thomas

20I3 The Experience of Citizenship and Nationhood through Sporting Practice in Solomon Islands. PhD dissertation, Department of Social Anthropology, University of Bergen. 
OFC, Oceania Football Confederation

2010 Activity Report 20IO. Auckland: ofC. http://www.oceaniafootball .com/ofc/Portals/o/Images/Articles/Activity_Report_20IO_FINAL .pdf [accessed Io Feb 20I4]

Olivier de Sardan, Jean-Pierre

2005 Anthropology and Development: Understanding Contemporary Social Change. London: Zed Books.

Sahlins, Marshall

I992 The Economics of Develop-man in the Pacific. Res 2I:I3-25.

Sillitoe, Paul

2010 Trust in Development: Some Implications of Knowing in Indigenous Knowledge. Journal of the Royal Anthropological Institute I6 (I): I 2-30.

Thomas, Nicholas

I997 Colonialism's Culture: Anthropology, Travel, and Government. Princeton: Princeton University Press.

UN Department of Public Information

2005 The Millennium Development Goals Report (DPI/2390). May. New York: United Nations Department of Public Information.

UN Interagency Task Force on Sport for Development and Peace

[2003] Sport as a Tool for Development and Peace: Towards Achieving the United Nations Millennium Development Goals. [March.] http:// www.un.org/sport2005/resources/task_force.pdf [accessed Io Feb 20I4]

West, Paige

2006 Environmental Conservation and Mining: Between Experience and Expectation in the Eastern Highlands of Papua New Guinea. The Contemporary Pacific I 8:295-3I3.

\section{Abstract}

This article addresses particular ideas behind the ideological discourses and practices of development relating to Solomon Islands soccer and the dissemination of knowledge applied to sporting practice. Speaking through the interconnection of local processes linked to global flows of information and practices, this analysis focuses on specific recent attempts by the global governing body FIFA and its regional representative, the $\mathrm{OFC}$, to introduce and implement various development programs under the objectives set out in official statutes. I further assess the disparate set of practices and conceptions of the various actors following the I998-2003 “Tension" period as part of a broader discourse of development sys- 
tems and interaction. By examining forms of "empowerment" discourse, appropriated by local agents as well as foreign organizations such as FIFA, this article suggests a more nuanced and pluralized approach to rethinking contemporary sporting formations and the competing knowledge systems at play throughout the region.

KEYWORDs: Solomon Islands, soccer, development, FIFA, sport 